\title{
EVALUASI KETERGUNAAN WEBSITE PERPUSTAKAAN UNIVERSITAS INDONESIA MENGGUNAKAN SYSTEM USABILITY SCALE
}

\author{
Muhammad Lazuardi Nuriman ${ }^{1^{*}}$, Nina Mayesti ${ }^{2}$ \\ ${ }^{1,2}$ Departmen Ilmu Perpustakaan dan Informasi, Fakultas Ilmu Pengetahuan Budaya, \\ Universitas Indonesia
}

*Korespondensi: lazuuardinuriman@gmail.com

Diajukan: 04-03-2020; Direview: 05-07-2020; Diterima: 05-09-2020; Direvisi: 25-09-2020

\begin{abstract}
The University of Indonesia (UI) Library has a website that is accessed by students to meet their information needs. Evaluation of usability on the university library website is important so that users remain loyal to visit it and the results can be used as a basis for further development. This study aims to evaluate the usability on the University Indonesia Library website between the batch of 2016 and 2019 and compare its results. The method used in this study is descriptive quantitative using a questionnaire based on the System Usability Scale. Questionnaires are distributed online through instant messaging applications and social media. The research data were analyzed using the System Usability Scale score calculation technique, then the results were compared between the two batches. The results of the analysis showed that the batch of 2016 had a better website usability value than the batch of 2019. The two batches also have good user experience based on the five components of Nielsen's usability, namely learnability, efficiency, memorability, errors, and satisfaction. The usability of the Indonesian Library's website has not been well accepted by students of batch 2016 and 2019 , although there are differences in scores between the two batches. Because the SUS score is below average and below acceptable, further research can be conducted using different method or instrument to identify the existing problems.
\end{abstract}

\begin{abstract}
ABSTRAK
Perpustakaan Universitas Indonesia (UI) memiliki website yang diakses oleh mahasiswa untuk memenuhi kebutuhan informasinya. Evaluasi ketergunaan pada website perpustakaan perguruan tinggi penting untuk dilakukan agar pengguna tetap setia mengunjunginya dan hasilnya dapat dijadikan dasar untuk pengembangan lebih lanjut. Penelitian ini bertujuan untuk mengevaluasi ketergunaan pada website Perpustakaan UI antara angkatan 2016 dan 2019 serta membandingkan hasilnya. Metode yang digunakan adalah kuantitatif deskriptif dengan menggunakan kuesioner berdasarkan System Usability Scale. Kuesioner disebarkan secara daring melalui aplikasi pesan instan dan media sosial. Data penelitian dianalisis menggunakan teknik perhitungan skor System Usability Scale, kemudian hasilnya dibandingkan antara kedua angkatan. Hasil analisis menunjukkan bahwa angkatan 2016 memiliki nilai ketergunaan website yang lebih baik daripada angkatan 2019. Kedua angkatan juga memiliki pengalaman pengguna yang cukup baik berdasarkan lima komponen ketergunaan Nielsen, yaitu learnability, efficiency, memorability, errors, dan satisfaction. Nilai ketergunaan website Perpustakaan UI belum dapat diterima dengan baik oleh mahasiswa angkatan 2016 dan 2019, meskipun terdapat perbedaan skor antara kedua angkatan. Karena skor SUSnya tergolong di bawah rata-rata dan di bawah acceptable, maka penelitian lebih lanjut dapat dilakukan untuk mengidentifikasi masalah yang ada menggunakan metode atau instrumen yang berbeda.
\end{abstract}

Keywords: Library website; Academic library; User experience; Usability evaluation; System usability scale; Nielsen indicators

\section{PENDAHULUAN}

Evaluasi ketergunaan adalah penilaian terhadap suatu sistem dengan mendapatkan umpan balik dari pengguna mengenai bagaimana mereka belajar dan menggunakan suatu produk untuk meraih tujuan, serta bagaimana kepuasan dan kenyamanan mereka dalam menggunakan suatu sistem (Garrett, 2011). Perpustakaan Universitas Indonesia (UI) sebagai perpustakaan perguruan tinggi terbesar di Asia Tenggara memiliki website yang berisi informasi tentang perpustakaan beserta koleksinya. Dengan jumlah Mahasiswa UI sebanyak kurang lebih 7.000 untuk setiap angkatannya, mereka mengakses web perpustakaan untuk mencari koleksi. Pada mahasiswa tingkat 
akhir, mereka biasanya sudah mulai menulis tugas akhir sehingga membuat mereka menggunakan website perpustakaan untuk mencari referensi. Selain itu pada mahasiswa baru, meskipun baru menggunakan website sekitar empat bulan, mereka masih menggunakannya untuk mencari referensi tugas kuliah atau sekadar mencari buku bacaan untuk hiburan.

Peneliti ingin mengetahui perbandingan tingkat ketergunaan pada website UI melalui pengalaman pengguna, khususnya mahasiswa tingkat akhir dan mahasiswa baru. Penelitian ini penting untuk pengguna dalam mengunjungi website perpustakaan di perpustakaan perguruan tinggi dan menggunakan website dengan mudah dan nyaman. Selain itu, penelitian ini perlu dilakukan karena website Perpustakaan UI belum pernah dikaji masalah ketergunaannya.

Di Indonesia, penelitian dalam ranah interaksi komputer-manusia, khususnya mengenai ketergunaan di bidang ilmu perpustakaan dan informasi belum banyak dilakukan. Penelitian ini bertujuan untuk membantu pengembangan ketergunaan pada website perpustakaan dan menambah khazanah penelitian ketergunaan di bidang tersebut. Kemudahan dan kenyamanan akses terhadap koleksi perpustakaan melalui website merupakan hal penting karena dapat mempengaruhi kesetiaan pengguna dalam memanfaatkan layanan dan koleksi perpustakaan. Pengujian atau evaluasi ketergunaan website pun berperan penting bagi perpustakaan untuk tetap memenuhi kebutuhan informasi penggunanya. dan juga membantu dalam mengembangkan pendekatan baru pada akses informasi (Genuis, 2004).

Penelitian tentang evaluasi ketergunaan pada website perpustakaan, khususnya perpustakaan perguruan tinggi masih belum banyak dilakukan di Indonesia, terutama dalam bidang ilmu perpustakaan dan informasi. Rumbiak \& Setiawan (2017) melakukan penelitian tentang evaluasi ketergunaan pada website perpustakaan Universitas Multimedia Nusantara. Penelitian tersebut menggunakan kuesioner yang dibuat berdasarkan System Usability Scale (SUS) untuk menganalisis antarmuka pengguna pada website yang diteliti. Hasil penelitian menunjukkan bahwa beberapa antarmuka pengguna baru direkomendasikan untuk mengembangkan website perpustakaan yang sudah usang. Istiana (2011) menjelaskan bahwa evaluasi website akan sangat bermanfaat bagi perpustakaan untuk mengembangkan website yang dimiliki. Penelitian tersebut meneliti ketergunaan website Perpustakaan UGM yang menggunakan metode kuantitatif dengan metode survei. Hasil analisis menunjukkan bahwa website Perpustakaan UGM memiliki nilai ketergunaan yang baik karena bermanfaat bagi mahasiswa. Nilai ketergunaan tersebut dipengaruhi oleh faktor efektivitas, efisiensi, dan kepuasan, di mana masing-masing faktor memiliki pengaruh yang berbeda-beda.

Di beberapa negara lain, terdapat beberapa penelitian di bidang ketergunaan yang mengkaji website perpustakaan maupun sistem pembelajaran. Inal (2017) meneliti evaluasi ketergunaan dari website perpustakaan nasional Turki. Penelitian tersebut menggunakan metode penilaian berdasarkan Heuristik Nielsen yang ditunjang dengan SUS dan Net Promotor Score (NPS). Hasil penelitian menunjukkan bahwa partisipan menemui banyak masalah ketergunaan pada website tersebut dan menganggapnya memiliki karakteristik ketergunaan yang rendah. Jumlah total dari masalah ketergunaan dalam evaluasi heuristik berkorelasi secara signifikan dan negatif dengan hasil SUS dan NPS yang menunjukkan bahwa lebih banyak partisipan yang mengidentifikasi masalah ketergunaan, maka lebih kecil kemungkinan mereka menilai website tersebut dapat digunakan dengan baik.

Phongpaew \& Jiamsanguanwong (2018) meneliti tentang masalah utama antarmuka pada myCourseVille yang banyak digunakan universitas di Thailand untuk mendukung pembelajaran. Mereka menggunakan metode evaluasi ketergunaan yang dikaitkan dengan lima atribut ketergunaan pada antarmuka mahasiswa dan antarmuka dosen. Hasil penelitian menunjukkan bahwa sebagian besar dari pengguna puas dengan sistem tersebut dan tidak merasa kesulitan dalam mengaksesnya. Meskipun begitu, ada sedikit masalah ketergunaan seperti desain kompleks dan bahasa ambigu. Mereka menyarankan penelitian lebih lanjut untuk mengevaluasi sistem secara 
keseluruhan dan juga dapat menggunakan teknik lain untuk evaluasi. Kous et al. (2019) meneliti bagaimana pengguna dengan karakteristik berbeda menanggapi ketergunaan website perpustakaan. Mereka menggunakan metode pengujian ketergunaan formal yang mencakup protokol think-aloud, analisis log, dan kuesioner. Hasil penelitian menunjukkan bahwa kelompok pengguna yang berbeda memiliki perbedaan signifikan dalam hal efisiensi dan efektivitas, tapi tidak ada pada kepuasan. Penelitian tersebut menyarankan peningkatan pada kebermanfaatan website, terutama kepada pengguna yang tidak berpengalaman.

Perbedaan antara penelitian ini dengan keempat penelitian tersebut adalah pada cakupan lokasinya, yaitu Perpustakaan UI, dan melanjutkan penelitian oleh Kous, dkk. (2019) dengan mengevaluasi ketergunaan berdasarkan perbandingan antara dua angkatan mahasiswa yang berbeda, yaitu angkatan 2016 dan 2019, tanpa dijadikan dasar untuk perancangan antarmuka pengguna yang baru. Angkatan 2016 dipilih karena pada waktu penelitian, mereka berada di tingkat akhir sehingga banyak yang mencari sumber referensi untuk penelitian tugas akhir serta sudah berpengalaman menggunakan website Perpustakaan UI selama tiga tahun. Angkatan 2019 dipilih karena mereka merupakan mahasiswa baru dan baru menggunakan website tersebut selama tiga bulan. Penelitian ini menggunakan SUS karena mudah digunakan dan dapat menilai website secara keseluruhan, serta belum ada peneliti yang menggunakan alat tersebut untuk penelitian antarmuka pengguna khususnya pada website di bidang ilmu perpustakaan dan informasi di Indonesia. Selain itu, penelitian ini berusaha menjawab pertanyaan yaitu bagaimana tingkat ketergunaan pada website Perpustakaan UI berdasarkan evaluasi oleh mahasiswa angkatan 2016 dan 2019.

\section{TINJAUAN PUSTAKA}

\subsection{Perpustakaan Digital}

Perpustakaan digital adalah perpustakaan dimana sebagian besar sumber daya tersedia dalam format yang dapat dibaca oleh mesin (bukan cetak atau mikroform), dapat diakses dengan komputer (2014). Konten digital dapat diperoleh secara lokal atau diakses dari jarak jauh melalui jaringan komputer (Reitz, 2014). IFLA/UNESCO Manifesto for Digital Libraries (2014) mendefinisikan perpustakaan digital sebagai koleksi daring dari benda digital yang kualitasnya terjamin karena diciptakan atau dihimpun dan dikelola menggunakan prinsip-prinsip yang memungkinkan pengembangan, pengguna dapat mengakses secara koheren, berkelanjutan, dan mendukung layanan yang diperlukannya untuk temu kembali dan pemanfaatannya. Layanan perpustakaan dapat memiliki perpustakaan digital sebagai bagian integralnya yang menggunakan teknologi agar pengguna mendapat akses ke koleksi digital. Koleksi di dalam perpustakaan digital diciptakan, dikelola, dan dapat diakses dengan mudah dan cepat oleh masyarakat (IFLA, 2014).

\subsection{Pengalaman Pengguna}

Menurut ISO 9241-210 (2019), pengalaman pengguna (user experience) adalah reaksi pengguna terhadap penggunaan sebuah produk, sistem atau layanan yang diwujudkan dalam bentuk persepsi atau respon. Pengalaman pengguna mengkaji perilaku pengguna, seperti bagaimana mereka merasakan kesenangan dan kepuasan dalam menggunakan, melihat, atau memegang sebuah produk. Desainer produk, baik itu desainer grafis ataupun desainer user interface atau pengalaman pengguna tidak merancang pengalaman pengguna, akan tetapi dia dapat merancang sebuah produk yang menghasilkan pengalaman pengguna. Pengalaman pengguna sendiri merupakan bidang yang luas, mencakup berbagai bidang ilmu lain, seiring perkembangan bidang pengalaman pengguna itu sendiri. Bidang ilmu yang masuk dalam cakupan pengalaman pengguna termasuk antropologi kultural, interaksi komputer-manusia, arsitektur informasi, teknik, jurnalisme, psikologi, dan desain grafis (Stull, 2018). 


\subsection{Antarmuka Pengguna}

Antarmuka pengguna (user interface), terutama pada web, adalah rancangan, penyajian, dan eksekusi dari elemen-elemen yang menyusun suatu halaman web (Bank \& Cao, 2014). Pada dasarnya elemen-elemen tersebut bervariasi karena mencakup apa pun yang dapat diletakkan oleh perancang dalam website. Menurut McKay (2013), elemen-elemen tersebut dapat dimasukkan ke dalam lima bagian, antara lain 1) tujuan yaitu kegiatan yang dilakukan suatu elemen; 2) keterjangkauan yaitu petunjuk visual bagaimana melaksanakan suatu fungsi; 3) bahasa tubuh yaitu detail penyajian elemen yang menyediakan informasi tambahan di samping tujuan dan keterjangkauannya; 4) interaksi yaitu aksi spesifik pengguna untuk melakukan suatu interaksi dengan elemen; dan 5) pelabelan yang mencakup label teks, placeholder, ikon, atau tooltips yang menjelaskan maksud, kegunaan atau efek pada suatu elemen.

\subsection{Evaluasi Ketergunaan}

Menurut ISO 9241 - 210 (2019), ketergunaan adalah tingkatan sejauh mana pengguna merasa puas, efektif, dan efisien dalam menggunakan sebuah produk untuk mencapai suatu tujuan. Selain itu, pengertian ketergunaan secara umum adalah atribut dari kualitas yang digunakan untuk mengevaluasi tingkat kemudahan pada penggunaan suatu antarmuka. Nielsen (2012) mengatakan bahwa dalam pengujian ketergunaan pada website bertujuan untuk menilai pengalaman pengguna berdasarkan kriteria sebagai berikut.

1) Dapat dipelajari (learnability): tingkat kemudahan pengguna sehingga dapat menyelesaikan tugas-tugas dasar saat pertama kali mereka menemukan tampilan produk

2) Efisiensi (efficiency): tingkat kecepatan pengguna sehingga dapat melakukan tugas setelah mereka mempelajari tampilan produk.

3) Daya ingat (memorability): tingkat kemudahan pengguna dalam mempelajari dan menggunakan kembali suatu produk setelah tidak menggunakannya untuk beberapa saat.

4) Kesalahan (errors): tingkat kesalahan yang dilakukan oleh pengguna, tingkat keparahan dari kesalahan tersebut, dan tingkat kemudahan pengguna dalam pulih dari kesalahan yang telah dilakukan.

5) Kepuasan (satisfaction): tingkat kesenangan pengguna dalam menggunakan suatu produk.

Evaluasi ketergunaan menilai sejauh mana pengguna merasa interaktif, mudah, dan nyaman dalam menggunakan suatu produk atau sistem (Cockton, n.d.). Beberapa hal yang perlu dipertimbangkan dalam evaluasi ketergunaan, yakni sebagai berikut.

1) Ketergunaan adalah sifat bawaan yang dapat diukur dari semua teknologi digital interaktif.

2) Peneliti interaksi manusia-komputer dan profesional desain interaksi telah mengembangkan metode evaluasi yang menentukan apakah sistem atau perangkat interaktif dapat digunakan atau tidak.

3) Jika suatu sistem atau perangkat dapat digunakan, metode evaluasi ketergunaan juga menentukan tingkat kegunaannya, melalui penggunaan metrik yang kuat, objektif, dan andal.

4) Metode dan metrik evaluasi didokumentasikan secara menyeluruh dalam penelitian interaksi manusia-komputer dan literatur praktisi

Evaluasi ketergunaan dapat dilakukan menggunakan dua metode, yaitu kualitatif dan kuantitatif. Pada metode kuantitatif, evaluasi dapat dilakukan dengan menggunakan statistik. Dampak dari desain yang baik dan buruk dapat dikuantifikasi dengan mudah ke dalam konversi, tingkat penyelesaian, waktu penyelesaian, kepuasan yang dirasakan, rekomendasi, dan penjualan. Praktisi ketergunaan dan peneliti pengguna dapat menguantifikasi keuntungan dari usaha mereka untuk menilai ketergunaan produk yang telah dibuat (Sauro \& Lewis 2016). 


\subsection{System Usability Scale}

System Usability Scale (SUS) dibuat oleh John Brooke pada tahun 1986 untuk mengevaluasi berbagai jenis sistem atau produk secara praktis. SUS sudah dicoba dan diuji selama 30 tahun penggunaan, dan sudah terbukti menjadi metode yang dapat diandalkan untuk mengevaluasi ketergunaan sistem. SUS merupakan salah satu alat paling efisien untuk mengevaluasi ketergunaan sistem atau produk dengan mengumpulkan data yang valid secara statistik dan memberikan nilai yang jelas dan rasional pada website dengan tepat. Dibanding dengan alat uji lainnya, SUS lebih murah dan lebih cepat, dalam arti memiliki pertanyaan yang tidak terlalu banyak dan memiliki template yang dapat langsung digunakan. SUS dibuat untuk mengatasi kebutuhan akan kesederhanaan dan kecepatan dalam mengevaluasi sistem yang telah dibuat dan dapat digunakan dalam berbagai konteks maupun berbagai jenis sistem selain website, seperti operasi sistem, perangkat keras, perangkat lunak, dan aplikasi (Brooke 1996).

Ada tiga manfaat yang dapat diperoleh dengan menggunakan SUS, yaitu: (1) SUS merupakan skala yang mudah untuk diberikan kepada pengguna; (2) Hasil SUS dapat diandalkan meskipun menggunakan ukuran sampel yang kecil; dan (3) Hasil SUS bersifat valid, yaitu dapat membedakan antara sistem yang dapat digunakan dengan yang tidak dapat digunakan dengan efektif. Dalam menggunakan SUS, ada beberapa hal yang perlu dipertimbangkan, yaitu: (1) sistem penilaian yang cukup kompleks; (2) gangguan untuk menginterpretasikan skor akhir sebagai persentase; (3) cara terbaik untuk menginterpretasikan hasil melibatkan "menormalkan skor untuk menghasilkan peringkat persentil; (4) SUS tidak digunakan untuk mendiagnosis masalah yang ada dalam sistem, tetapi untuk mengklasifikasikan kemudahan penggunaan sistem yang diuji.

\section{METODE}

Metode yang digunakan dalam penelitian ini adalah kuantitatif - deskriptif. Menurut Rukajat (2018), metode deskriptif adalah metode penelitian untuk mengkaji status sekelompok manusia, objek, set kondisi, sistem pemikiran ataupun kelas peristiwa pada masa kini. Penelitian deskriptif bertujuan untuk menggambarkan fakta, sifat, atau hubungan antar objek atau fenomena yang diteliti secara sistematis, faktual, dan akurat. Penelitian deskriptif juga menerangkan hubungan, menguji, hipotesis-hipotesis, membuat prediksi serta mendapatkan arti dan implikasi dari suatu masalah yang ingin dipecahkan. Pengumpulan data dapat menggunakan teknik wawancara atau penyebaran kuesioner dengan menggunakan beberapa pertanyaan yang sudah dipersiapkan sebelumnya. Objek kajian penelitian ini adalah website Perpustakaan UI (http://www.lib.ui.ac.id) .

Penelitian dilakukan pada bulan November - Desember 2019 melalui kuesioner yang disebarkan secara daring melalui WhatsApp, Line, Facebook, Twitter, dan Instagram. Sampel penelitian ditentukan dengan teknik stratified random sampling, dimana responden dipilih berdasarkan karakteristik tertentu yang ada dalam suatu populasi secara acak (Creswell 2017). Sampel penelitian ini merupakan Mahasiswa UI yang sedang menempuh tahun ajaran 2019/2020 dan berada di jenjang S1, khususnya angkatan 2016 dan 2019. Kriteria ini dipilih karena mahasiswa angkatan 2016 sudah lebih berpengalaman dan lebih sering mengunjungi website Perpustakaan UI. Angkatan 2019 dipilih karena mereka sebagai mahasiswa baru tergolong masih belum terlalu lama dalam mengunjungi website Perpustakaan UI sehingga memiliki pengalaman yang berbeda dibandingkan angkatan 2016. Jumlah responden yang diambil minimal 15 orang yang mewakili tiap rumpun (Rumpun Ilmu Kesehatan yang terdiri dari Fakultas Kedokteran, Fakultas Kedokteran Gigi, Fakultas Kesehatan Masyarakat, Fakultas Farmasi, dan Fakultas Ilmu Keperawatan; Rumpun Sains dan Teknologi yang terdiri dari Fakultas Ilmu Komputer, Fakultas Matematika dan Ilmu Pengetahuan Alam, dan Fakultas Teknik, dan Rumpun Ilmu Sosial Humaniora yang terdiri dari 
Fakultas Ekonomi dan Bisnis, Fakultas Hukum, Fakultas Ilmu Administrasi, Fakultas Ilmu Sosial dan Ilmu Politik, Fakultas Ilmu Pengetahuan Budaya, dan Fakultas Psikologi). Jumlah ini ditentukan berdasarkan hasil penelitian Faulkner (2003) yang menyatakan bahwa jumlah responden minimal 15 orang memberikan hasil yang lebih baik, dimana masalah yang didapatkan lebih banyak, yaitu minimal sebesar $90 \%$.

Instrumen penelitian ini adalah kuesioner yang mengacu pada indikator System Usability Scale (SUS) dan skala kuantitatif Likert dari 1 (satu) sampai 5 (lima). Skala ini menyatakan kesetujuan dan ketidaksetujuan pengguna. Setelah data diperoleh, analisis dilakukan menggunakan metode perhitungan SUS, kemudian hasil akhirnya dibandingkan dan diinterpretasi yang dikaitkan dengan lima komponen ketergunaan, yaitu learnability, efficiency, memorability, errors, dan satisfaction. Menurut Soejono, Setyanto, \& Sofyan (2018), aspek learnability, efficiency, dan memorability berkaitan dengan pertanyaan nomor 1, 3, 5, 7, dan 9. Aspek errors berkaitan dengan pertanyaan 2, 4, 6, 8, dan 10. Kemudian aspek satisfaction berkaitan dengan pertanyaan nomor 1 dan 9.

\section{HASIL DAN PEMBAHASAN}

\subsection{Profil Responden}

Setelah kuesioner disebar selama 14 hari (29 November 2019 - 12 Desember 2019) diketahui ada 144 responden yang mengisi kuesioner. Data tersebut kemudian dibagi menjadi dua bagian, yaitu angkatan 2016 dan 2019 (Tabel 1).

Tabel 1. Asal Rumpun untuk Responden Angkatan 2016 dan 2019

\begin{tabular}{|c|c|c|c|c|c|}
\hline \multirow{2}{*}{ Rumpun } & \multirow{2}{*}{ Fakultas } & \multicolumn{2}{|c|}{2016} & \multicolumn{2}{|l|}{2019} \\
\hline & & Frekuensi & $\%$ & Frekuensi & $\%$ \\
\hline \multirow[t]{7}{*}{ Sosial Humaniora } & & 42 & 58 & 50 & 69 \\
\hline & FEB & 1 & 1 & 2 & 3 \\
\hline & FH & 2 & 3 & 1 & 1 \\
\hline & FIA & 3 & 4 & 3 & 4 \\
\hline & FIB & 30 & 42 & 36 & 50 \\
\hline & FISIP & 4 & 6 & 6 & 8 \\
\hline & FPsi & 2 & 3 & 2 & 3 \\
\hline \multirow[t]{4}{*}{$\begin{array}{l}\text { Sains dan } \\
\text { Teknologi }\end{array}$} & & 16 & 22 & 10 & 14 \\
\hline & Fasilkom & 1 & 1 & 1 & 1 \\
\hline & FMIPA & 12 & 17 & 5 & 7 \\
\hline & FT & 3 & 4 & 4 & 6 \\
\hline \multirow[t]{7}{*}{ Ilmu Kesehatan } & & 14 & 19 & 12 & 17 \\
\hline & Farmasi & 3 & 4 & 2 & 3 \\
\hline & FIK & 5 & 7 & 5 & 7 \\
\hline & FK & 0 & 0 & 1 & 1 \\
\hline & FKG & 3 & 4 & 2 & 3 \\
\hline & FKM & 3 & 4 & 2 & 3 \\
\hline & Total & 72 & 100 & 72 & 100 \\
\hline
\end{tabular}

Berdasarkan Tabel 1, responden untuk angkatan 2016 sebagian besar berasal dari Rumpun Sosial Humaniora, yaitu sebanyak 42 responden (58\%). Pada rumpun ini, responden terbanyak berasal dari FIB (Fakultas Ilmu Pengetahuan Budaya), yaitu 30 responden (42\%), diikuti oleh FISIP (Fakultas Ilmu Sosial dan Ilmu Politik) sebanyak 4 responden (6\%), FIA (Fakultas Ilmu Administrasi) sebanyak 3 responden (4\%), FH (Fakultas Hukum) dan FPsi (Fakultas Psikologi) masing-masing sebanyak 2 responden (3\%), dan paling sedikit berasal dari FEB (Fakultas Ekonomi dan Bisnis) sebanyak 1 responden (1\%). 
Responden terbanyak kedua berasal dari Rumpun Sains dan Teknologi sebanyak 16 responden (22\%). Pada rumpun ini, responden terbanyak berasal dari FMIPA (Fakultas Matematika dan Ilmu Pengetahuan Alam), yaitu sebanyak 12 responden (17\%), diikuti oleh FT (Fakultas Teknik) sebanyak 3 responden (4\%), dan paling sedikit berasal dari Fasilkom (Fakultas Ilmu Komputer) sebanyak 1 responden $(1 \%)$.

Responden terbanyak ketiga berasal dari Rumpun Ilmu Kesehatan yaitu sebanyak 14 responden (19\%). Pada rumpun ini, responden terbanyak berasal dari FIK (Fakultas Ilmu Keperawatan) sebanyak 5 responden (7\%), diikuti oleh Fakultas Farmasi, FKG (Fakultas Kedokteran Gigi), dan FKM (Fakultas Kesehatan Masyarakat) masing-masing sebanyak 3 responden (4\%), dan tidak ada responden yang berasal dari FK (Fakultas Kedokteran). Kemudian pada angkatan 2019, sebagian besar responden berasal dari Rumpun Sosial Humaniora sebanyak 50 responden (69\%). Pada rumpun ini, sebagian besar responden berasal dari FIB (Fakultas Ilmu Pengetahuan Budaya) sebanyak 36 responden (50\%), diikuti oleh FISIP (Fakultas Ilmu Sosial dan Ilmu Politik) sebanyak 6 responden (8\%), FIA (Fakultas Ilmu Administrasi) sebanyak 3 responden (4\%), FEB (Fakultas Ekonomi dan Bisnis) dan FPsi (Fakultas Psikologi) masing-masing sebanyak 2 responden (3\%), lalu paling sedikit berasal dari FH (Fakultas Hukum) sebanyak 1 responden $(1 \%)$.

Responden terbanyak kedua berasal dari Rumpun Ilmu Kesehatan yaitu sebanyak 12 responden (17\%). Pada rumpun ini, responden terbanyak berasal dari FIK yaitu sebanyak 5 responden (7\%), diikuti oleh Fakultas Farmasi, FKG (Fakultas Kedokteran Gigi), dan FKM (Fakultas Kesehatan Masyarakat) masing-masing sebanyak 2 responden (3\%), dan paling sedikit berasal dari FK (Fakultas Kedokteran), yaitu sebanyak 1 responden (1\%). Responden terbanyak ketiga berasal dari Rumpun Sains dan Teknologi sebanyak 10 responden (14\%). Pada rumpun ini, responden terbanyak berasal dari FMIPA (Fakultas Matematika dan Ilmu Pengetahuan Alam), yaitu sebanyak 5 responden (7\%), diikuti oleh FT (Fakultas Teknik) sebanyak 4 responden (6\%), dan paling sedikit berasal dari Fasilkom (Fakultas Ilmu Komputer) yaitu sebanyak 1 responden (1\%). Berdasarkan Tabel 1 tersebut, masing-masing angkatan sama-sama didominasi oleh responden yang berasal dari Rumpun Sosial Humaniora. Sampel juga dapat dikatakan representatif karena mewakili ketiga rumpun yang ada di UI, meskipun pada Rumpun Ilmu Kesehatan angkatan 2016 tidak ada responden yang berasal dari Fakultas Kedokteran.

Tabel 2 menunjukkan sebagian besar responden dari angkatan 2016 mengunjungi website Perpustakaan UI dengan frekuensi kadang-kadang, dengan jumlah 21 responden atau sebesar $29 \%$. Sebanyak 2 atau 3\% dari responden angkatan 2016 sangat jarang mengunjungi website Perpustakaan UI.

Tabel 2. Frekuensi Kunjungan ke Website untuk Angkatan 2016 dan 2019

\begin{tabular}{|l|c|c|c|c|}
\hline \multirow{2}{*}{$\begin{array}{c}\text { Frekuensi } \\
\text { Kunjungan }\end{array}$} & \multicolumn{2}{c|}{ 2016 } & \multicolumn{2}{c|}{$\mathbf{2 0 1 9}$} \\
\cline { 2 - 5 } & Frekuensi & \% & Frekuensi & \% \\
\hline Sangat sering & 10 & 14 & 5 & 7 \\
\hline Sering & 31 & 43 & 19 & 26 \\
\hline Kadang-kadang & 21 & 29 & 27 & 38 \\
\hline Jarang & 7 & 10 & 16 & 22 \\
\hline Sangat jarang & 2 & 3 & 5 & 7 \\
\hline Total & 72 & 100 & 72 & 100 \\
\hline
\end{tabular}

Tabel 2 menunjukkan responden dari angkatan 2019 mengunjungi website Perpustakaan UI dengan frekuensi kadang-kadang, dimana jumlah responden untuk frekuensi tersebut adalah 27 responden atau sebesar 38\%. Responden yang sangat sering maupun sangat jarang mengunjungi website Perpustakaan UI memiliki jumlah yang sama, yaitu sebanyak 5 responden (7\%) dari keseluruhan sampel. Berdasarkan data tersebut, Mahasiswa UI angkatan 2016 dan 2019 memiliki perbedaan 
frekuensi dalam mengunjungi website Perpustakaan UI. Mahasiswa angkatan 2016 sebagian besar sering mengunjungi website, sedangkan sebagian besar dari mahasiswa angkatan 2019 kadangkadang mengunjungi website.

\subsection{Analisis Ketergunaan dengan System Usability Scale}

Setelah data terkumpul, data yang diperoleh untuk 10 pertanyaan SUS dihitung dengan cara sebagai berikut.

1) Skor pertanyaan dengan nomor ganjil $(1,3,5,7,9)=$ nilai dari responden -1

2) Skor pertanyaan dengan nomor genap $(2,4,6,8,10)=5$ - nilai dari responden

3) Setelah mendapat hasil dari pengurangan semua pertanyaan di atas, semua hasilnya dijumlahkan kemudian dikalikan 2,5 untuk mendapatkan hasil dengan nilai maksimal 100.

Skor dari masing-masing responden dijumlahkan kemudian dihitung rata-ratanya sehingga menghasilkan skor akhir SUS (Tabel 3). Penghitungan skor untuk masing-masing angkatan 2016 dilakukan secara terpisah, kemudian hasilnya dibandingkan dan diinterpretasi menurut Grading Scale Nilai SUS (Tabel 4) oleh Bangor, Kortum, \& Miller (2009) dan Sauro \& Lewis (2016).

Tabel 3. Hasil Skor SUS untuk Angkatan 2016 dan 2019

\begin{tabular}{|c|c|c|c|}
\hline Angkatan & N & Skor Akhir & Nilai Huruf \\
\hline 2016 & 72 & 63,89 & C- \\
\hline 2019 & 72 & 59,38 & D \\
\hline
\end{tabular}

Tabel 4. Grading Scale Nilai SUS

\begin{tabular}{|l|l|l|l|l|l|}
\hline Grade & \multicolumn{1}{|c|}{ SUS } & $\begin{array}{c}\text { Percentile } \\
\text { range }\end{array}$ & \multicolumn{1}{|c|}{ Adjective } & \multicolumn{1}{|c|}{ Acceptable } & NPS \\
\hline A+ & $84.1-100$ & $96-100$ & Best Imaginable & Acceptable & Promoter \\
\hline A & $80.8-84.0$ & $90-95$ & Excellent & Acceptable & Promoter \\
\hline A- & $78.9-80.7$ & $85-89$ & Excellent & Acceptable & Promoter \\
\hline B+ & $77.2-78.8$ & $80-84$ & Excellent & Acceptable & Promoter \\
\hline B & $74.1-77.1$ & $70-79$ & Excellent & Acceptable & Passive \\
\hline B- & $72.6-74.0$ & $65-69$ & Excellent & Acceptable & Passive \\
\hline C+ & $71.1-72.5$ & $60-64$ & Good & Acceptable & Passive \\
\hline C & $65.0-71.0$ & $41-59$ & Good & Marginal & Passive \\
\hline C- & $62.7-64.9$ & $35-40$ & Good & Marginal & Passive \\
\hline D & $51.7-62.6$ & $15-34$ & OK & Marginal & Detractor \\
\hline F & $25.1-51.6$ & $2-14$ & Poor & Not Acceptable & Detractor \\
\hline F & $0-25$ & $0-1.9$ & Worst Imaginable & Not Acceptable & Detractor \\
\hline
\end{tabular}

Tabel 4 menunjukkan bahwa pada angkatan 2016, skor rata-ratanya adalah 63,89 sedangkan pada angkatan 2019 skor akhirnya adalah 59,38. Angkatan 2016 memiliki skor akhir SUS yang lebih tinggi daripada angkatan 2019. Kedua angkatan memiliki skor yang berada di bawah rata-rata SUS yang bernilai 68. Menurut Grading Scale SUS yang dibuat oleh Sauro-Lewis (2016) dan Rating Scale yang dibuat oleh (Bangor, Kortum, \& Miller 2009), skor SUS oleh angkatan 2016 jika dikonversi menjadi nilai huruf adalah C-, sedangkan untuk angkatan 2019 adalah D.

Jika dikonversi ke nilai persentil, skor SUS untuk angkatan 2016 berada pada rentang $35-40$, sedangkan skor SUS untuk angkatan 2019 berada pada rentang 15 - 34. Nilai persentil menunjukkan bahwa suatu website memiliki ketergunaan yang lebih baik daripada website dengan nilai persentil di bawahnya dan lebih buruk daripada website dengan nilai persentil di atasnya. Hasil konversi tersebut menunjukkan bahwa untuk angkatan 2016, mereka menilai bahwa website Perpustakaan UI memiliki ketergunaan yang lebih baik daripada 34\% website tapi lebih buruk dari $60 \%$ website lain yang pernah dinilai ketergunaannya menggunakan SUS. Pada angkatan 2019, 
mereka menilai bahwa website Perpustakaan UI memiliki ketergunaan yang lebih baik dari $14 \%$ website lainnya dan lebih buruk dari $66 \%$ website lainnya. Secara keseluruhan, website Perpustakaan UI memiliki ketergunaan yang lebih baik dari $14 \%$ website lain dan lebih buruk dari $60 \%$ website lainnya.

Untuk skala sifat (adjective), skor SUS untuk angkatan 2016 dapat digolongkan menjadi baik (Good) dan cukup baik (OK) untuk angkatan 2019. Dari penggolongan tersebut dapat dilihat bahwa website Perpustakaan UI memiliki ketergunaan yang baik oleh angkatan 2016 dan cukup baik oleh angkatan 2019. Artinya, angkatan 2016 menilai bahwa website Perpustakaan UI sudah nyaman dan mudah untuk digunakan, sedangkan angkatan 2019 menilai bahwa website Perpustakaan UI masih cukup nyaman dan cukup mudah untuk digunakan. Meskipun begitu, website Perpustakaan UI perlu diperbaiki. Perbedaan angkatan ini mempengaruhi penilaian mereka terhadap website Perpustakaan UI, di mana angkatan 2016 menilai lebih baik yang ditunjukkan oleh skor SUS yang lebih tinggi dari angkatan 2019 karena mereka sudah lebih lama mengunjungi website Perpustakaan UI sehingga memiliki pengalaman yang lebih baik dan lebih mengetahui apa yang ada serta bagaimana cara melakukan sesuatu di website tersebut. Untuk tingkat penerimaan, skor SUS untuk kedua angkatan tergolong marginal, yaitu antara diterima (acceptable) dan tidak diterima (not acceptable). Hal ini menunjukkan bahwa ketergunaan website Perpustakaan UI kurang diterima oleh kedua angkatan. Mereka belum bisa menerima bahwa website Perpustakaan UI memiliki ketergunaan yang baik.

Berdasarkan nilai NPS (Net Promoter Score), skor SUS untuk angkatan 2016 tergolong Passive, untuk angkatan 2019 tergolong Detractor. NPS digunakan untuk menghitung tingkat kemauan konsumen dalam merekomendasi suatu produk. Passive artinya angkatan 2016 tidak terlalu puas tapi dapat berpindah dengan mudah ke kompetitor lain jika ada kesempatan. Detractor artinya angkatan 2019 tidak terlalu terpuaskan dengan website Perpustakaan UI. Oleh karena itu, kedua angkatan tidak terpuaskan dan tidak akan merekomendasikan website Perpustakaan UI.

\subsection{Keterkaitan Skor SUS dengan Lima Komponen Ketergunaan Nielsen}

\section{1) Aspek Learnability, Efficiency, dan Memorability}

Gambar 1 menunjukkan bahwa sebagian besar responden pada angkatan 2016, yaitu sebanyak 38 responden menanggapi sangat setuju untuk Pertanyaan 1, yaitu "saya berpikir akan menggunakan website ini lagi”.

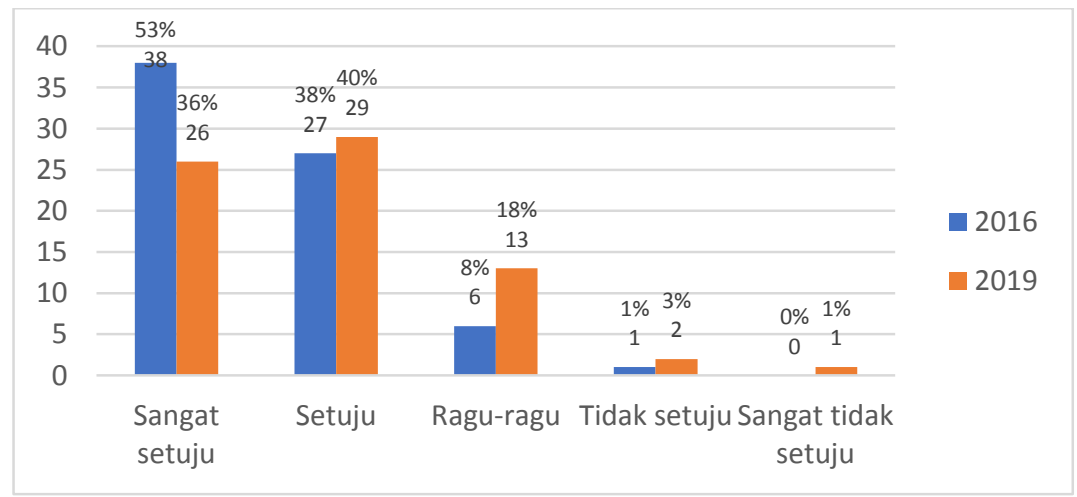

Gambar 1. Pertanyaan 1 angkatan 2016 dan 2019

Kemudian sebagian besar dari angkatan 2019, sebanyak 29 responden menanggapi setuju. Data tersebut menunjukkan bahwa kedua angkatan menilai bahwa website Perpustakaan UI mudah dan nyaman digunakan sehingga membuat mereka ingin menggunakannya lagi, khususnya yang berkaitan dengan aspek learnability. 


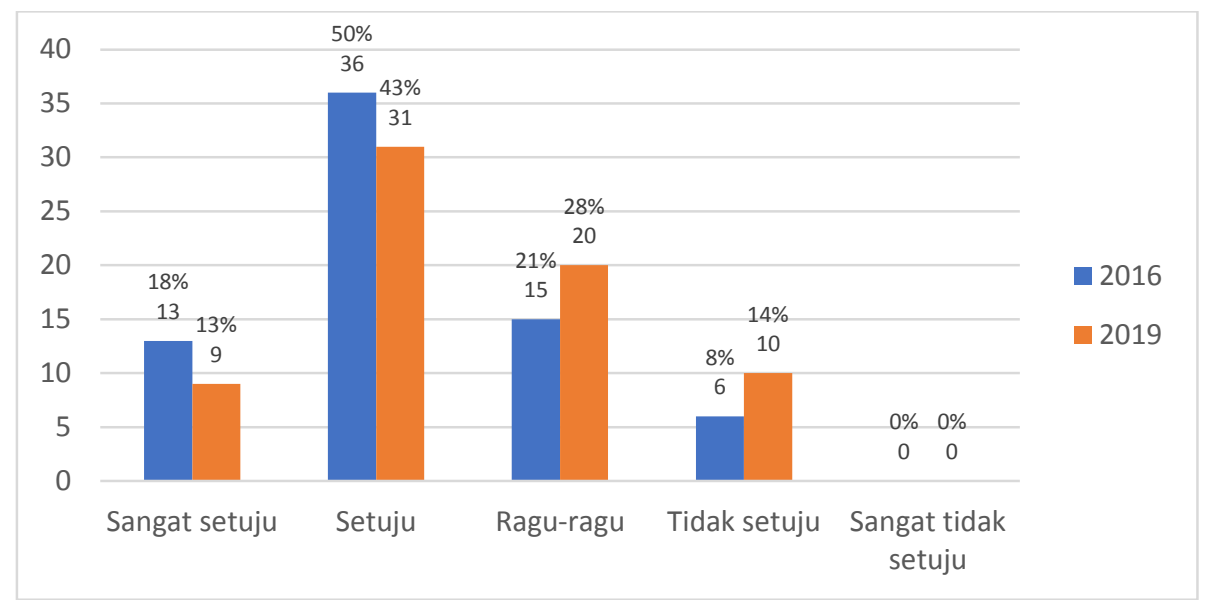

Gambar 2. Pertanyaan 3 angkatan 2016 dan 2019

Gambar 2 menunjukkan bahwa sebagian besar responden pada angkatan 2016, yaitu sebanyak 36 responden (50\%) menanggapi setuju untuk Pertanyaan 3, yaitu "saya merasa website ini mudah digunakan". Kemudian sebagian besar dari angkatan 2019, sebanyak 31 responden juga menanggapi setuju. Data tersebut menunjukkan bahwa sebagian besar dari kedua angkatan tidak menemui kesulitan berarti dalam menggunakan website Perpustakaan UI. Hal tersebut berkaitan dengan aspek learnability dan efficiency.

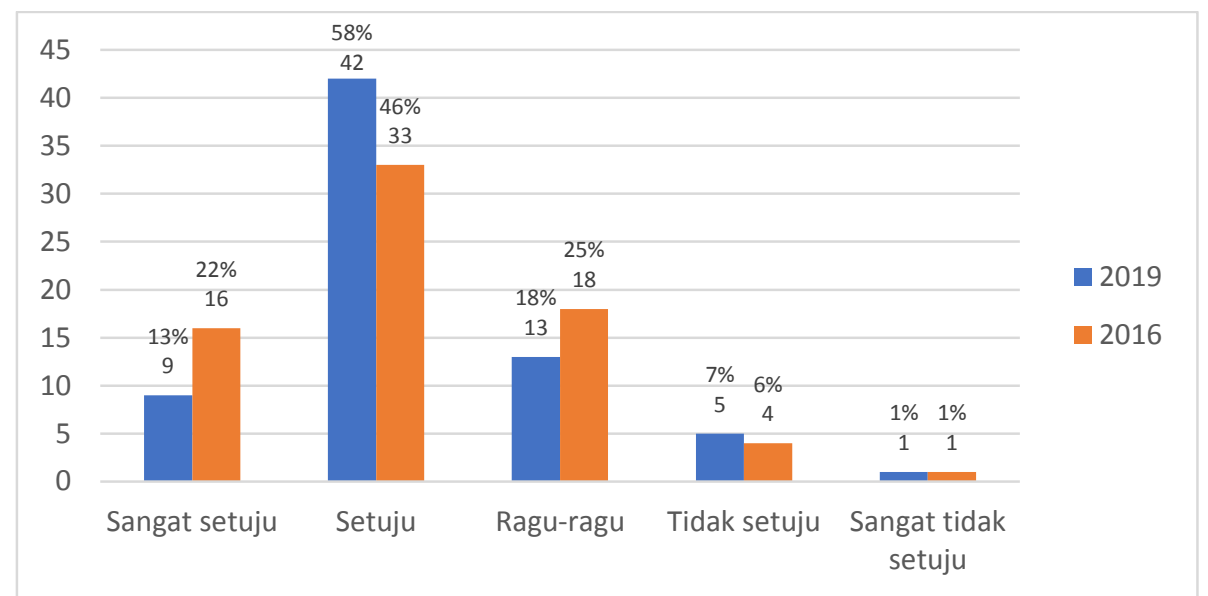

Gambar 3. Pertanyaan 5 angkatan 2016 dan 2019

Gambar 3 menunjukkan bahwa sebagian besar responden pada angkatan 2016, yaitu sebanyak 42 responden menanggapi sangat setuju untuk Pertanyaan 5, yaitu "saya merasa fitur-fitur website ini berjalan dengan semestinya". Kemudian sebagian besar dari angkatan 2019, sebanyak 33 responden juga menanggapi setuju. Data tersebut menunjukkan bahwa sebagian besar dari kedua angkatan menemukan bahwa fitur-fitur yang ada di website Perpustakaan UI berfungsi dengan baik, sehingga mereka dapat menggunakan website Perpustakaan UI dengan nyaman. Dengan kata lain, sebagian besar dari kedua angkatan setuju bahwa website tersebut dapat digunakan secara efisien. 


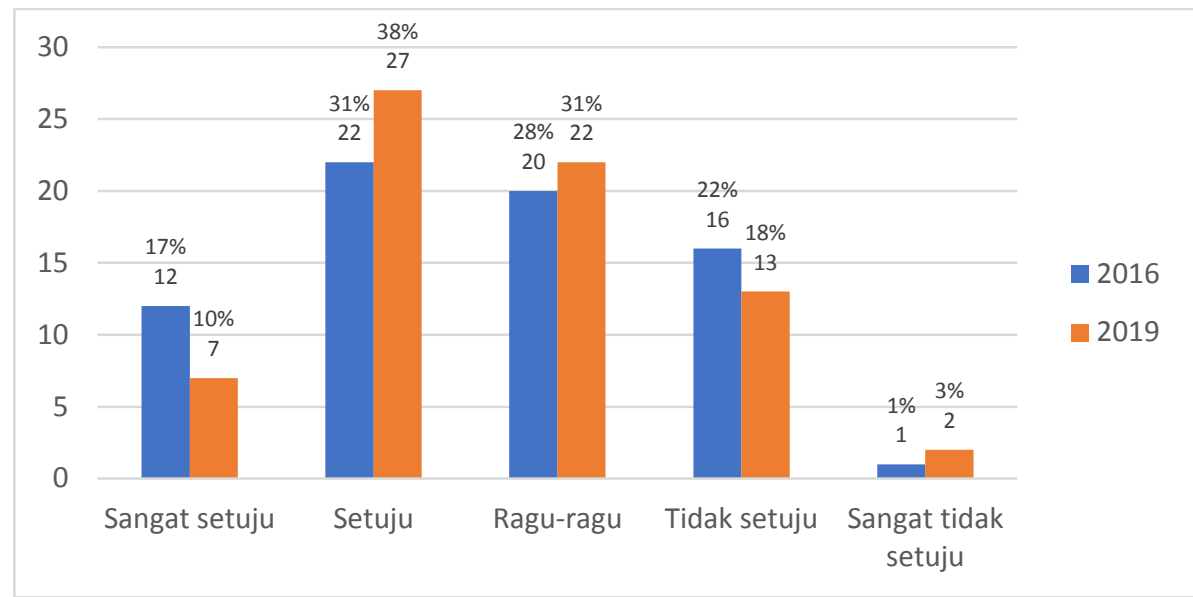

Gambar 4. Pertanyaan 7 angkatan 2016 dan 2019

Gambar 4 menunjukkan bahwa sebagian besar responden pada angkatan 2016, yaitu sebanyak 22 responden menanggapi sangat setuju untuk Pertanyaan 7, yaitu "saya merasa orang lain akan memahami cara menggunakan website dengan cepat". Kemudian sebagian besar dari angkatan 2019, sebanyak 27 responden juga menanggapi setuju. Data tersebut menunjukkan bahwa sebagian besar responden dari angkatan 2016 dan 2019 menilai bahwa website Perpustakaan UI mudah dipelajari oleh orang lain, yang mana berkaitan erat dengan aspek learnability, efficiency, dan memorability. Artinya, website tersebut memiliki tampilan yang bekerja secara efisien dan mudah diingat, sehingga memudahkan pengunjung baru untuk mempelajari website tersebut dengan cepat tanpa kesusahan.

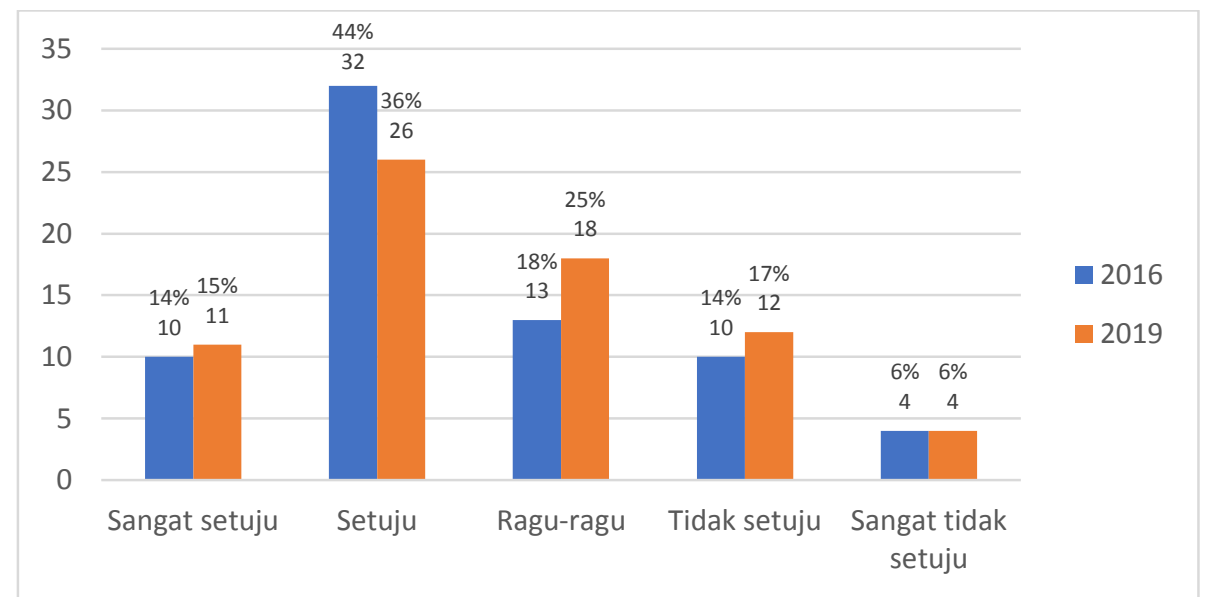

Gambar 5. Pertanyaan 9 angkatan 2016 dan 2019

Gambar 5 menunjukkan bahwa sebagian besar responden pada angkatan 2016, yaitu sebanyak 32 responden (44\%) menanggapi sangat setuju untuk Pertanyaan 9, yaitu "saya merasa tidak ada hambatan dalam menggunakan website". Kemudian sebagian besar dari angkatan 2019, sebanyak 26 responden (36\%) juga menanggapi setuju. Data tersebut menunjukkan bahwa sebagian besar dari kedua angkatan menilai bahwa website Perpustakaan UI dapat digunakan dengan mudah dan nyaman tanpa hambatan. Hal tersebut berkaitan erat dengan aspek efficiency, di mana fitur-fitur dalam website tersebut dapat bekerja secara sederhana dan dengan cepat, sehingga tidak membuat pengguna kerepotan maupun kesulitan dalam menggunakannya.

Berdasarkan kelima gambar tersebut, sebagian besar responden, baik angkatan 2016 maupun 2019 menanggapi setuju dalam menilai aspek learnability, efficiency, dan memorability, meskipun pada pertanyaan 1, yaitu "saya berpikir akan menggunakan website ini lagi" 
sebagian besar responden dari angkatan 2016 menanggapi sangat setuju. Hal ini menunjukkan bahwa sebagian besar responden dapat mempelajari website dengan baik dan cepat (learnability), menggunakannya secara efisien tanpa hambatan (efficiency), serta mengingat dengan baik tanpa perlu belajar lagi dari awal ketika mengunjungi website Perpustakaan UI (memorability). Oleh karena itu, website Perpustakaan UI memiliki tampilan antarmuka yang sederhana, sehingga dapat dipelajari dengan mudah dan cepat, dan juga dapat digunakan dengan mudah dan nyaman tanpa hambatan. Karena kesederhanaan tersebut, pengguna juga tidak akan kesulitan dalam mengingat letak suatu fitur seperti kotak pencarian, menu utama, sehingga ketika mereka mengunjunginya kembali mereka tidak harus mempelajarinya lagi.

\section{2) Aspek Errors}

Gambar 6 menunjukkan bahwa sebagian besar responden pada angkatan 2016, yaitu sebanyak 33 responden (46\%) menanggapi tidak setuju untuk Pertanyaan 2, yaitu "saya merasa website ini rumit untuk digunakan". Kemudian sebagian besar dari angkatan 2019, sebanyak 23 responden (32\%) juga menanggapi tidak setuju.

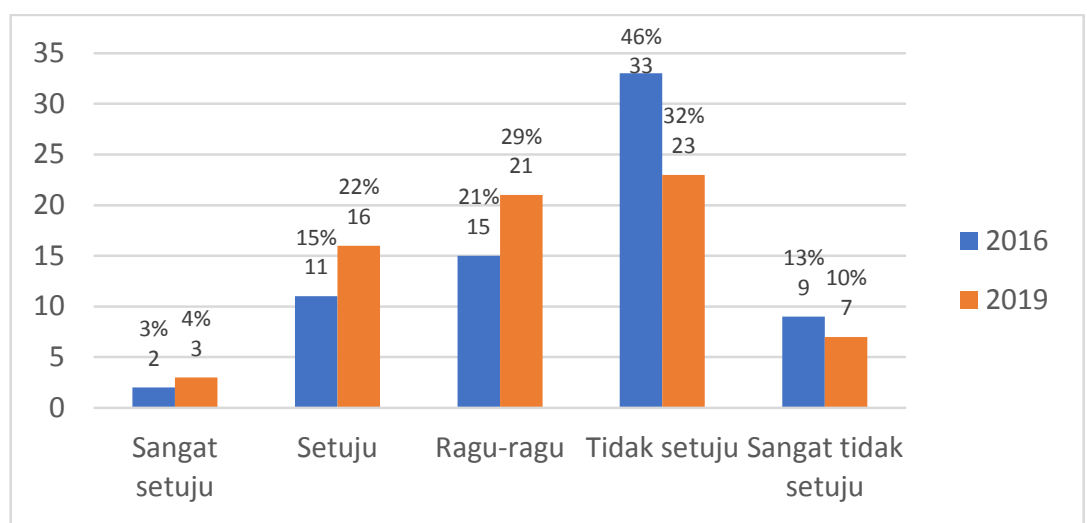

Gambar 6. Pertanyaan 2 angkatan 2016 dan 2019

Data tersebut menunjukkan bahwa sebagian besar dari kedua angkatan menemukan bahwa website Perpustakaan UI mudah digunakan tanpa atau dengan sedikit kesalahan. Dengan kata lain, website tersebut memiliki tingkat kesalahan (errors) yang rendah, hanya saja penelitian ini tidak mengukur sejauh mana tingkat kesalahan yang dapat terjadi dalam penggunaan website Perpustakaan UI.

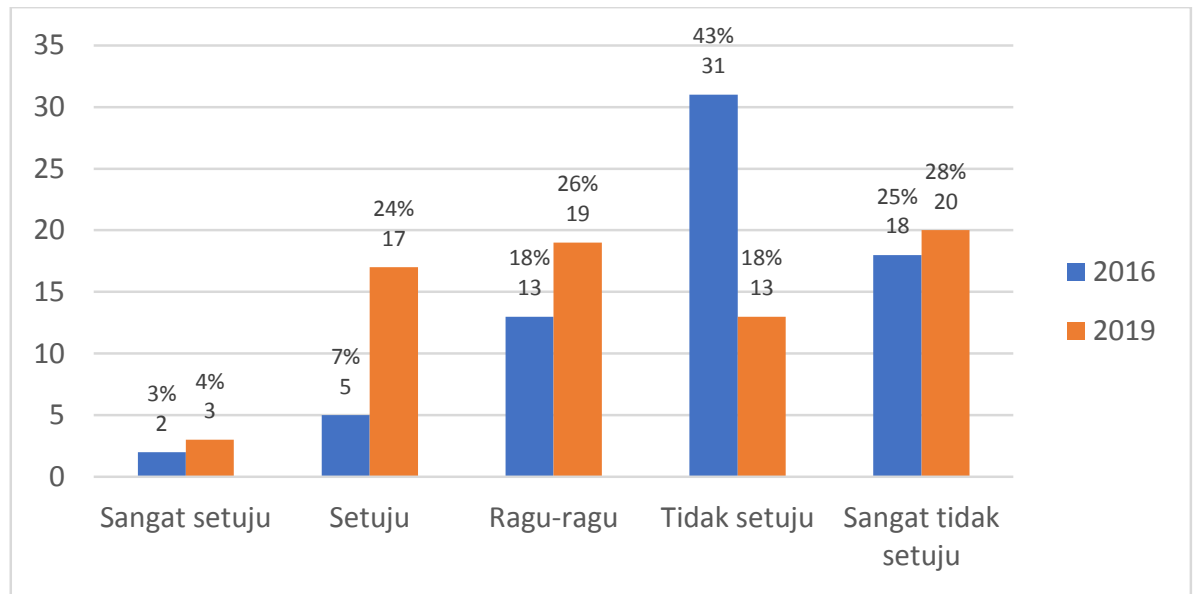

Gambar 7. Pertanyaan 4 angkatan 2016 dan 2019 
Gambar 7 menunjukkan bahwa sebagian besar responden pada angkatan 2016, yaitu sebanyak 31 responden (43\%) menanggapi tidak setuju untuk Pertanyaan 4, yaitu "saya membutuhkan bantuan dari orang lain atau teknisi dalam menggunakan website ini". Kemudian sebagian besar dari angkatan 2019, sebanyak 20 responden (28\%) menanggapi sangat tidak setuju. Data tersebut menunjukkan bahwa sebagian besar dari kedua angkatan dapat mempelajari cara menggunakan website Perpustakaan UI secara mandiri tanpa bantuan orang lain. Artinya, jarang terjadi kesalahan (errors) pada website tersebut, terutama kesalahan yang tidak dapat diatasi sendiri.

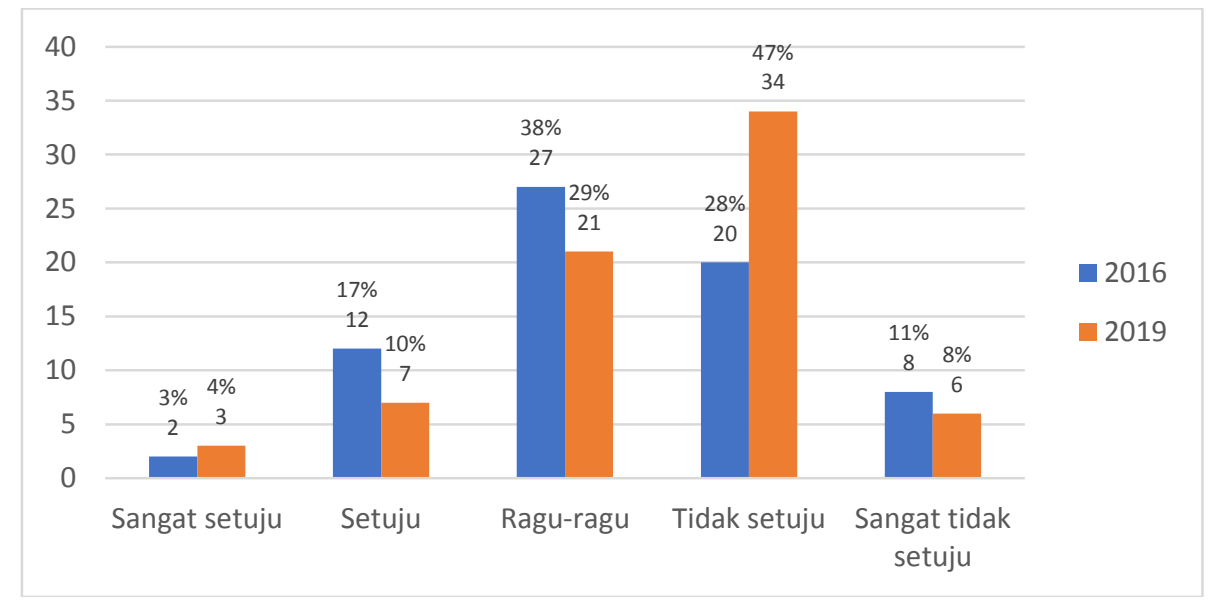

Gambar 8. Pertanyaan 6 Angkatan 2016 dan 2019

Gambar 8 menunjukkan bahwa sebagian besar responden pada angkatan 2016, yaitu sebanyak 34 responden menanggapi tidak setuju untuk Pertanyaan 6, yaitu "saya merasa ada banyak hal yang tidak konsisten (tidak serasi pada website ini)". Kemudian sebagian besar dari angkatan 2019, sebanyak 27 responden menanggapi ragu-ragu. Data tersebut menunjukkan bahwa sebagian besar dari angkatan 2016 menilai bahwa banyak fitur di website Perpustakaan UI berfungsi secara konsisten, sedangkan sebagian besar dari angkatan 2019 ragu-ragu terhadap hal tersebut. Perbedaan penilaian pada kedua angkatan dapat menunjukkan bahwa website tersebut memiliki sedikit inkonsistensi, karena pertanyaan tersebut bersifat umum, maka tidak dapat diketahui dengan pasti inkonsistensi seperti apa yang ada pada website Perpustakaan UI.

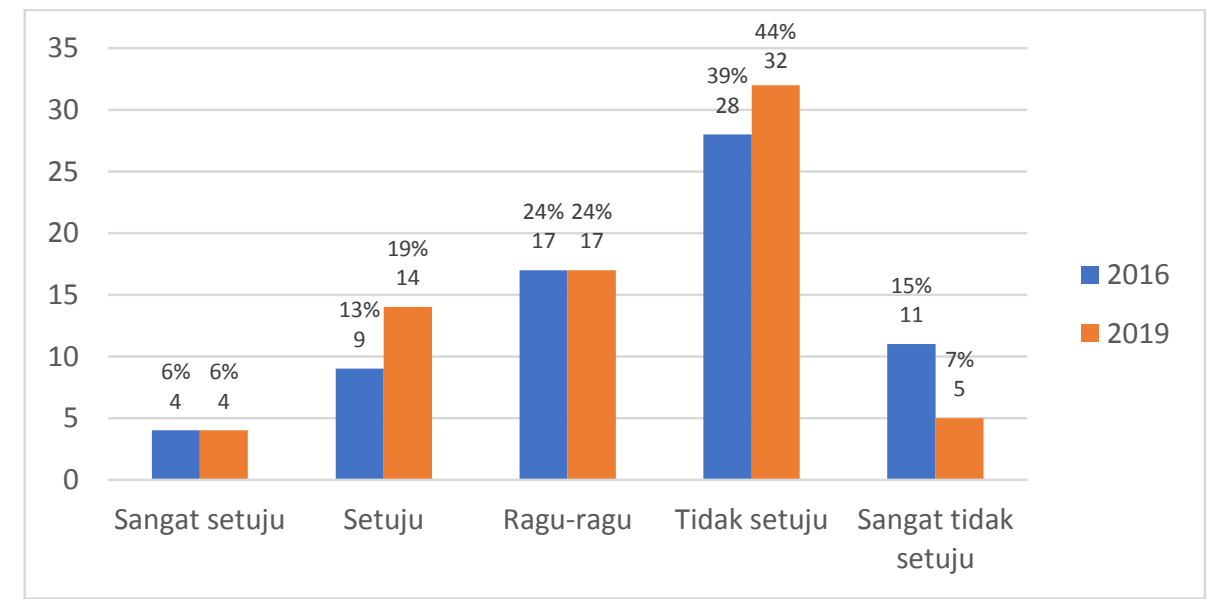

Gambar 9. Pertanyaan 8 angkatan 2016 dan 2019

Gambar 9 menunjukkan bahwa sebagian besar responden pada angkatan 2016, yaitu sebanyak 32 responden menanggapi tidak setuju untuk Pertanyaan 8, yaitu "saya merasa website ini 
membingungkan". Kemudian sebagian besar dari angkatan 2019, sebanyak 28 responden juga menanggapi tidak setuju. Data tersebut menunjukkan bahwa sebagian besar dari kedua angkatan menilai bahwa website Perpustakaan UI dapat digunakan dengan mudah tanpa membuat mereka bingung, sehingga mereka dapat menghindari atau mencegah kesalahan. Website Perpustakaan UI dapat dikatakan memiliki tampilan yang membuat penggunanya dapat melakukan tugas-tugas tertentu dengan jelas dan pasti, sehingga mereka tidak akan kebingungan dan dapat menghindari kesalahan dalam menggunakan website.

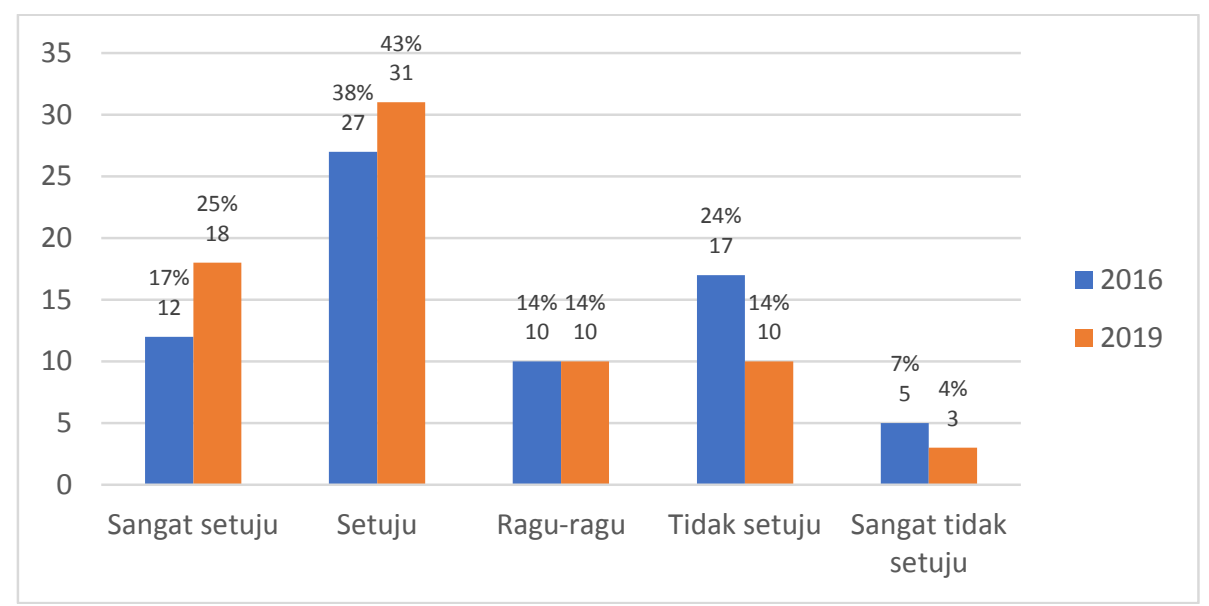

Gambar 10. Pertanyaan 10 angkatan 2016 dan 2019

Gambar 10 menunjukkan bahwa sebagian besar responden pada angkatan 2016, yaitu sebanyak 31 responden menanggapi sangat setuju untuk Pertanyaan 10, yaitu "saya perlu membiasakan diri terlebih dahulu sebelum menggunakan website ini". Kemudian sebagian besar dari angkatan 2019, sebanyak 27 responden menanggapi setuju. Data tersebut menunjukkan bahwa sebagian besar dari kedua angkatan memerlukan waktu untuk beradaptasi dan mempelajari website Perpustakaan UI. Website tersebut memiliki sedikit kesalahan yang membuat pengguna memerlukan waktu untuk mempelajari cara menggunakannya.

Berdasarkan kelima gambar tersebut, sebagian besar responden, baik angkatan 2016 maupun 2019 menanggapi sangat tidak setuju dan tidak setuju dalam menilai aspek errors, meskipun pada pertanyaan 10, yaitu "saya perlu membiasakan diri terlebih dahulu sebelum menggunakan website ini" sebagian besar dari mereka menanggapi setuju. Hasil analisis tersebut menunjukkan bahwa sebagian besar responden melakukan sedikit kesalahan, dan dapat belajar cepat dari kesalahan ketika mengunjungi website Perpustakaan UI. Oleh karena itu, website Perpustakaan UI memiliki tampilan dan fitur yang berfungsi dengan baik, dimana pengguna menemui sedikit kesalahan (errors), sehingga lebih mudah dan nyaman.

\section{3) Aspek Satisfaction}

Gambar 11 menunjukkan bahwa sebagian besar responden pada angkatan 2016, yaitu sebanyak 38 responden (53\%) menanggapi sangat setuju untuk Pertanyaan 1, yaitu "saya berpikir akan menggunakan website ini lagi". Kemudian sebagian besar dari angkatan 2019, sebanyak 29 responden (40\%) menanggapi setuju. 


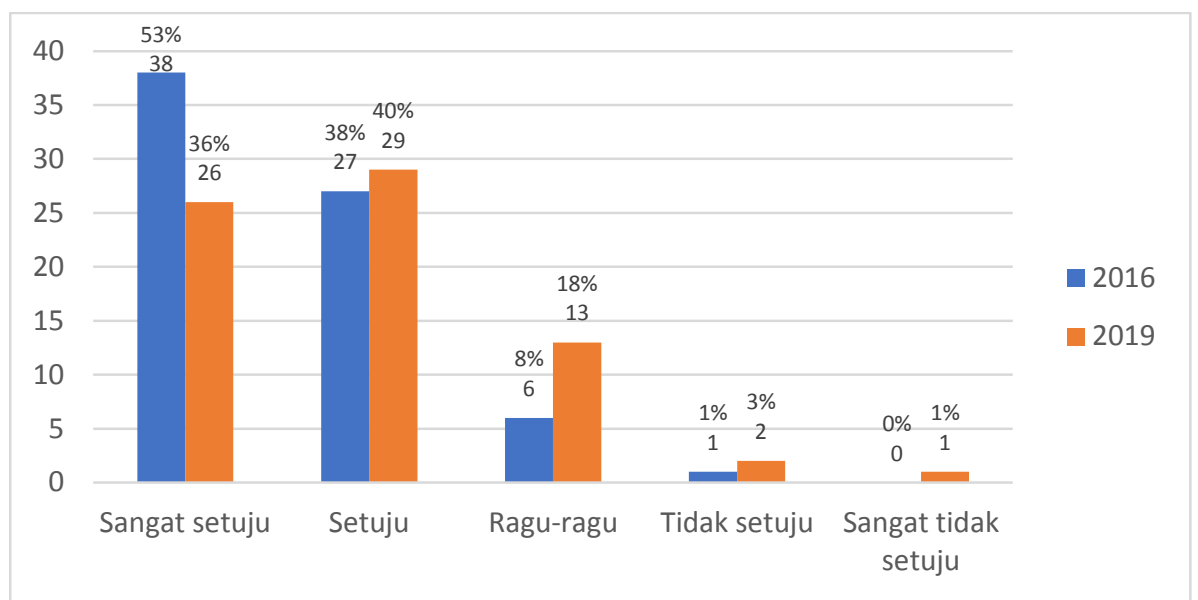

Gambar 11. Pertanyaan 1 angkatan 2016 dan 2019

Data tersebut menunjukkan bahwa sebagian besar dari kedua angkatan menilai bahwa website Perpustakaan UI mudah dan nyaman digunakan sehingga mereka mau mengunjunginya lagi. Artinya, sebagian besar responden dari kedua angkat merasa puas terhadap pengalaman mereka dalam menggunakan website tesebut.

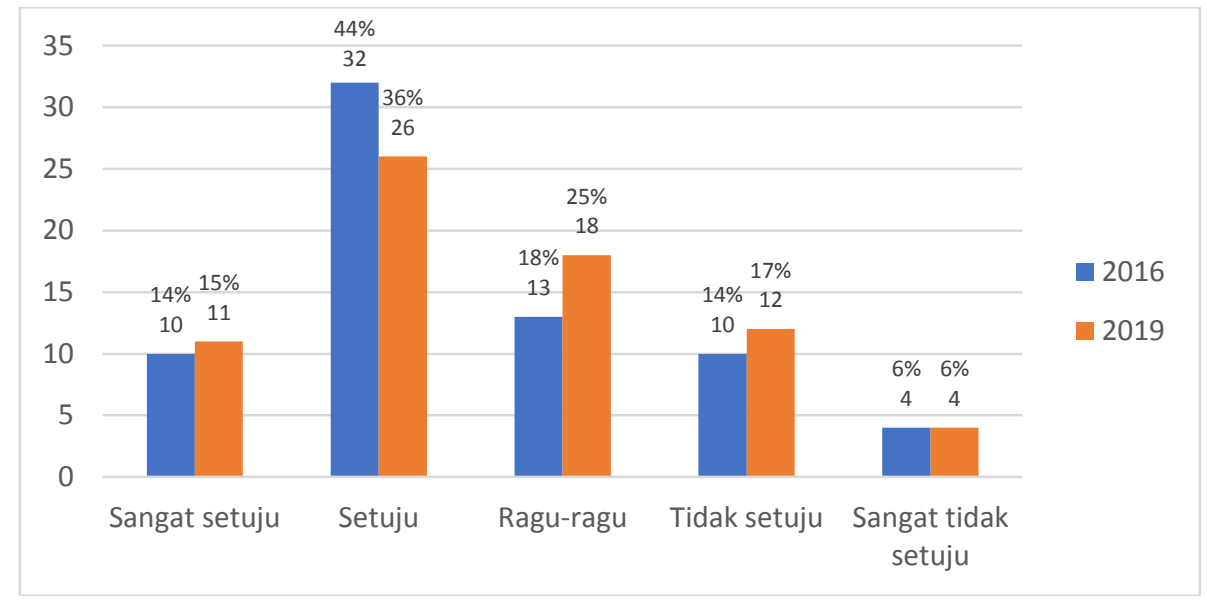

Gambar 12. Pertanyaan 9 angkatan 2016 dan 2019

Gambar 5 menunjukkan bahwa sebagian besar responden pada angkatan 2016, yaitu sebanyak 32 responden (44\%) menanggapi setuju untuk Pertanyaan 9, yaitu "saya merasa tidak ada hambatan dalam menggunakan website ini". Sebagian besar dari angkatan 2019, sebanyak 26 responden (36\%) juga menanggapi setuju. Data tersebut menunjukkan bahwa sebagian besar dari kedua angkatan dapat menggunakan website Perpustakaan UI dengan mudah dan nyaman tanpa hambatan. Sebagian besar responden dari kedua angkatan setuju bahwa mereka puas karena mereka merasa tidak ada hambatan dalam menggunakan website tersebut.

Berdasarkan kedua gambar tersebut, ada sedikit perbedaan pada responden dalam menilai aspek satisfaction. Untuk pertanyaan 1, yaitu "saya berpikir akan menggunakan website ini lagi”, sebagian besar dari angkatan 2016 menganggapi sangat setuju, sedangkan sebagian besar angkatan 2019 menanggapi setuju. Kemudian untuk pertanyaan 9, yaitu "saya merasa tidak ada hambatan dalam menggunakan website ini”, sebagian besar dari kedua angkatan sama-sama menanggapi setuju. Meskipun terdapat sedikit perbedaan tanggapan, dapat dikatakan bahwa sebagian besar responden merasa puas dengan pengalaman mereka dalam mengunjungi dan menggunakan website Perpustakaan UI. 


\section{KESIMPULAN}

Secara keseluruhan, tingkat ketergunaan pada website UI belum dapat diterima dengan baik oleh angkatan 2016 dan 2019. Adanya perbedaan skor menunjukkan bahwa angkatan 2016 lebih tinggi daripada angkatan 2019, atau angkatan 2016 memiliki penilaian yang lebih baik dalam mengevaluasi ketergunaan website Perpustakaan UI. Meskipun kedua angkatan memiliki perbedaan skor SUS, mereka juga memiliki kesamaan dalam menilai kelima komponen ketergunaan Nielsen yang dikaitkan dengan kesepuluh butir pertanyaan dalam SUS. Sebagian besar dari kedua angkatan memiliki kemampuan yang baik dalam aspek learnability, efficiency, dan memorability; dapat menangani kesalahan (errors) dengan baik; dan merasa puas dengan website Perpustakaan UI. Berdasarkan skor SUS pada mahasiswa angkatan 2016 dan 2019, website Perpustakaan UI memiliki ketergunaan yang baik (Good) dan cukup baik (OK), tapi masih belum dapat diterima (acceptable) dan juga memerlukan perbaikan. Skor dari kedua angkatan berada di bawah skor rata-rata SUS, yang tergolong di bawah acceptable, sehingga perlu ada penelitian lanjutan pada website Perpustakaan UI untuk mengidentifikasi berbagai permasalahan pengguna dalam menggunakan metode atau instrumen yang berbeda.

\section{DAFTAR PUSTAKA}

Bangor, A., Kortum, P., \& Miller, J. 2009. Determining What Individual SUS Scores Mean: Adding An Adjective Rating Scale. Journal of usability studies, 4(3), 114-23.

Bank, C. \& Cao, J. 2014. UX Design Process \& Documentation. UXPin. https://doi.org/10.1126/science.98.2540.213.

Brooke, J. 1996. SUS-A Quick and Dirty Usability Scale. Usability Evaluation in Industry, 189(194), 4-7.

Cockton, G. n.d. Usability Evaluation. The Encyclopedia of Human-Computer Interaction. (2nd ed.). di https://www.interaction-design.org/literature/book/the-encyclopedia-of-human-computerinteraction-2nd-ed/usability-evaluation.

Creswell, J. W. 2017. Research Design: Qualitative, Quantitative, And Mixed Methods Approaches. SAGE Publications.

Faulkner, L. 2003. Beyond The Five-User Assumption: Benefits of Increased Sample Sizes in Usability Testing. Behavior Research Methods, Instruments, and Computers, 35(3), 379-83. https://doi.org/10.3758/BF03195514.

Garrett, J.J. 2011. The Elements of User Experience: User-Centered Design for The Web and Beyond, (2nd ed). Berkeley: New Riders.

Genuis, S.K. 2004. Web Site Usability Testing: A Critical Tool for Libraries Usability testing in library. Feliciter, 4, 161-64.

IFLA. 2014. IFLA/UNESCO Manifesto for Digital Libraries. di http://www.ifla.org/publications/iflaunesco-manifesto-for-digital-libraries.

Inal, Y. 2017. University Students' Heuristic Evaluation of The National Library of Turkey Website. ASLIB: Journal of Information Management, 70(1), 66-77. https://doi.org/ 10.1108/AJIM-092017-0216.

ISO. 2019. ISO 9241-210:2019 Ergonomics of Human-System Interaction - Part 210: HumanCentred Design For Interactive Systems. di https://www.iso.org/obp/ui/\#iso:std:iso:9241:210:ed-2:v1:en. 
Istiana, P. 2011. Evaluasi Usability Situs Web Perpustakaan. Visi Pustaka, 13(3), 5-10.

Kous, K., Pušnik, M., Heričko, M. \& Polančič, G. 2019. Usability Evaluation of a Library Website with Different End User Groups. Journal of Librarianship and Information Science, 1(1), 1-16.

McKay, E. 2013. UI is Communication: How To Design Intuitive, User-Centered Interfaces by Focusing on Effective Communication. Burlington: Morgan Kaufmann.

Nielsen, J. 2012. Nielsen Norman Group Usability 101: Introduction to usability. Nielsen Norman Group. https://doi.org/10.1097/JTO.0b013e3181b27170\r01243894-200909002-00002.

Phongphaew, N. \& Jiamsanguanwong, A. 2018. Usability Evaluation on Learning Management System. Advances in Usability and User Experience, 607, 39-48. https://doi.org/10.1007/978-3319-60492-3_4

Reitz, J. M. 2014. Online Dictionary for Library and Information Science. ABC-CLIO > ODLIS > D. di https://www.abc-clio.com/ODLIS/odlis_d.aspx.

Rukajat, A. 2018. Pendekatan Penelitian Kuantitatif: Quantitative Research Approach. Deepublish.

Rumbiak, M. \& Setiawan, J. 2017. Evaluasi Usability Website library.umn.ac.id Universitas Multimedia Nusantara. Ultima InfoSys: Jurnal Ilmu Sistem Informasi, 8(2), 87-94. https://doi.org/https://doi.org/10.31937/si.v8i2.618

Sauro, J. \& Lewis, J. R. 2016. Quantifying the User Experience: Practical Statistics for User Research. Burlington: Morgan Kaufmann.

Soejono, Wibowo, A., Setyanto, A., \& Sofyan, A.F. 2018. Evaluasi Usability Website UNRIYO Menggunakan System Usability Scale (Studi Kasus: Website UNRIYO). Jurnal Teknologi Informasi Respati, 13(1), 29-37. https://doi.org/10.35842/jtir.v13i1.213.

Stull, E. 2018. UX fundamentals for non-UX professionals. https://doi.org/10.1007/978-1-4842-38110 . 